\title{
Ivabradin při srdečním selhání zastavuje remodelaci myokardu
}

Nová data o pozitivním dopadu farmakologického sniženi srdečni frekvence u pacientů se srdečním selháním byla prezentována na nedávném výročním zasedáni Evropské kardiologické společnosti v Pařiži. Šlo o předem specifikované podstudie studie SHIFT, zarazené do prestižni sekce Clinical Trial Updates.

U savců lze vysledovat až pozoruhodně těsný stav mezi délkou života a srdeční frekvencí. Živočichové s nižší frekvencí (např. slon nebo velryba) žijí déle než ti, jimž srdce bije rychle. Celkový počet srdečních stahů za život je u všech savců velmi podobný, a to navzdory obrovským rozdílům v celkové hmotnosti i tepovém objemu. Klidová tepová frekvence je u člověka silným a nezávislým prognostickým faktorem, který informuje o možném riziku budoucích kardiovaskulárních i nekardiovaskulárních př́hod. Čím je její hodnota vyšší, tím vyšší je riziko kardiovaskulární mortality i morbidity, včetně výskytu náhlé srdeční smrti. Zvýšení srdeční frekvence o 20 tepů za minutu zvyšuje riziko úmrtí z kardiovaskulárních příčin zhruba o $40 \%$ - přibližně podobně jako zvýšení krevního tlaku o 15-20 mm Hg. Pomalejší srdeční frekvence je zřejmě spojena i s nižším rizikem ruptury nestabilního aterosklerotického plátu.

\section{Snížení srdeční frekvence - nic míň, nic víc}

Myšlenka ochrany myokardu právě prostřednictvím zpomalení srdeční frekvence samozřejmě nepřišla až v 21. století. Látky, jež $\mathrm{k}$ tomu dosud bylo možné použít, však měly celou řadu dalších účinkủ, a také bylo těžké dosáhnout toho, aby pacienti tolerovali potřebnou dávku, což se týká především beta-blokátorů. Své limity samozřejmě mají i bradykardizující blokátory kalciových kanálů, tedy diltiazem či verapamil, o kardiotonikách nemluvě. První molekulou, která nezpůsobuje nic jiného než právě a jen snížení srdeční frekvence, je ivabradin (Procoralan). Jde o selektivní blokátor kanálu $f$. Působí prostřednictvím specifické inhibice kardiálního pacemakerového $\mathrm{I}_{\mathrm{f}}$ proudu, který kontroluje spontánní diastolickou depolarizaci v sinusovém uzlu. Účinky na srdce jsou specifické, pouze na sinusový uzel, bez účinku na intraatriální, atrioventrikulární nebo intraventrikulární časy vedení, na myokardiální kontraktilitu nebo ventrikulární repolarizaci.

Obecně lze říci, že cílem léčby zaměřené na zpomalení rytmu je dosažení takové co nejnižší frekvence, kterou pacient ještě dobře toleruje, a tu pak dlouhodobě udržovat. $Z$ tohoto pohledu je ivabradin výhodný, protože mechanismus jeho účinku obsahuje jakousi „bezpečnostní pojistku“ - aby byl účinný, musí proniknout dovnitř buněčného kanálu $f$. Tyto kanály jsou však otevřené pouze při vyšší frekvenci, při nižší se uzavírají a bradykardizující účinek ivabradinu se neuplatňuje.

Ivabradin byl původně vyvinut $\mathrm{k}$ léčbě nemocných s anginou pectoris, $\mathrm{z}$ této terapie však profitují i pacienti se srdečním selháním. Pozitivní účinek ivabradinu u této velké skupiny nemocných potvrdila studie SHIFT (Systolic Heart Failure Treatment with the $\mathrm{I}_{\mathrm{f}}$ Inhibitor Ivabradine Trial), jejíž závěry byly prezentovány na loňském kongresu Evropské kardiologické společnosti (European Society of Cardiology, ESC) ve Stock- holmu. Šlo o mezinárodní, multicentrickou, randomizovanou, dvojitě zaslepenou studii, do níž bylo zařazeno 6558 nemocných se středně těžkým až těžkým systolickým srdečním selháním (funkční třídy NYHA II až IV). Pacienti byli rozděleni na skupinu léčenou ivabradinem dvakrát denně $5 \mathrm{mg}$ (dávka mohla být zvýšena na 7,5 mg dvakrát denně) a skupinu placebovou. Nemocní museli být v předchozích 12 měsících hospitalizováni pro zhoršenou srdeční insuficienci, s poklesem ejekční frakce pod 0,35 a klidovou srdeční frekvencí $\geq 70$ tepů za minutu. Průměrný věk nemocných byl 60 let, tři čtvrtiny byli muži a průměrná tepová frekvence při randomizaci byla 80 tepů za minutu. Téměř $90 \%$ nemocných užívalo beta-blokátory a $93 \%$ blokátory RAAS (inhibitory ACE či sartany).

$\mathrm{U}$ pacientů léčených ivabradinem došlo $\mathrm{k}$ poklesu tepové frekvence z 80 tepů za minutu na 64 tepů za minutu po jednom roce léčby, resp. 67 tepů za minutu po 3,5 letech sledování. V placebové skupině byl zaznamenán pokles z 80 na 75 tepů za minutu po celou dobu sledování. Ivabradin snížil riziko kardiovaskulární úmrtnosti nebo hospitalizací pro srdeční selhání (primární cílový ukazatel) o $18 \%(p<0,0001)$. Přidání ivabradinu ke standardní léčbě snížilo riziko úmrtí na srdeční selhání o $26 \%(p=0,014)$ a hospitalizace pro zhoršené srdeční selhání taktéž o vysoce významných $26 \%(p<0,0001)$.

Léčba ivabradinem byla bezpečná a dobře tolerovaná, s minimálním rizikem bradykardií či poruch vedení, včetně síňových fibrilací, jak dokázal 24hodinový holterovský monitoring. $\mathrm{Z}$ principu svého mechanismu účinku ivabradin navíc neovlivňuje krevní tlak.

$\mathrm{Na}$ letošním zasedání ESC, jež proběhlo na konci srpna v Pařiži, pak byla prezentována další data vyplývající z tohoto hodnocení v prestižní sekci věnované aktualizaci závěrů významných klinických studií.

První podstudie prokázala pozitivní účinek ivabradinu na kvalitu života a také fakt, že toto zlepšení je přímo úměrné snížení srdeční frekvence (SHIFT-HQoL, Health-related Quality of Life). Hodnocení zahrnovalo 1944 pacientů s chronickým srdečním selháním z 24 zemí, kteří byli navíc ke standardní léčbě srdečního selhání ( $90 \%$ pacientů užívalo beta-blokátory, $98 \%$ inhibitory ACE či sartany, $65 \%$ blokátor aldosteronu) randomizováni k užívání bud' ivabradinu, nebo placeba. Metodika byla založena na použití standardizovaného dotazníku KCCQ (Kansas City Cardiomyopathy Questionnaire) zahrnujícího jak otázky související s fyzickým omezením a symptomy pacientů se srdečním selháním (tzv. klinické skóre CSS - clinical summary score), tak otázky související se subjektivním vnímáním kvality života ve smyslu zdraví pacienta a jeho sociálního omezení (tzv. celkové skóre OSS - overall summary score). Zvláštní důraz byl kladen na sledování typických symptomů srdečního selhání, jakými jsou dušnost a únava. 
Zpomalení srdeční akce, jehož bylo dosaženo při léčbě ivabradinem, bylo spojeno $s$ téměř dvojnásobným zlepšením kvality života ve srovnání s kvalitou života u kontrolní skupiny. Pacienti udávali lepší kvalitu života jak v klinickém skóre CSS $(p=0,018)$, tak v celkovém skóre OSS $(p<0,001)$ (viz obr. 1$)$.

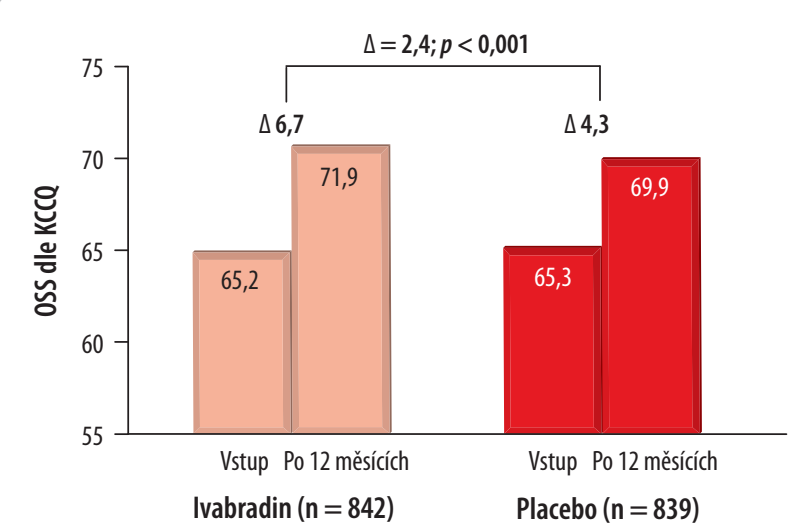

Ekman I. Eur Heart J. doi:10.1093/eurheartj/ehr343.

Obr. 1 Celkové souhrnné skóre OSS - změna po 12 měsících léčby

Podstudie studie SHIFT - HQoL (Health-related Quality of Life) tedy prokázala, že u pacientů se srdečním selháním a systolickou dysfunkcí je nízká kvalita života vztažená ke zdraví spojena $\mathrm{s}$ vyšší mírou úmrtí $\mathrm{z}$ kardiovaskulárních př́ícin nebo hospitalizací pro srdeční selhání. Již po 12 měsících léčby se prokázala jasná souvislost mezi incidencí sledovaných klinických událostí (úmrtí z kardiovaskulárních příčin nebo hospitalizace pro srdeční selhání) a kvalitou života vztaženou ke zdraví. Snížení srdeční frekvence ivabradinem (Procoralanem) přitom vede $\mathrm{k}$ lepší kvalitě života a míra poklesu srdeční frekvence po léčbě ivabradinem přímo souvisí se stupněm zlepšení kvality života (viz obr. 2).

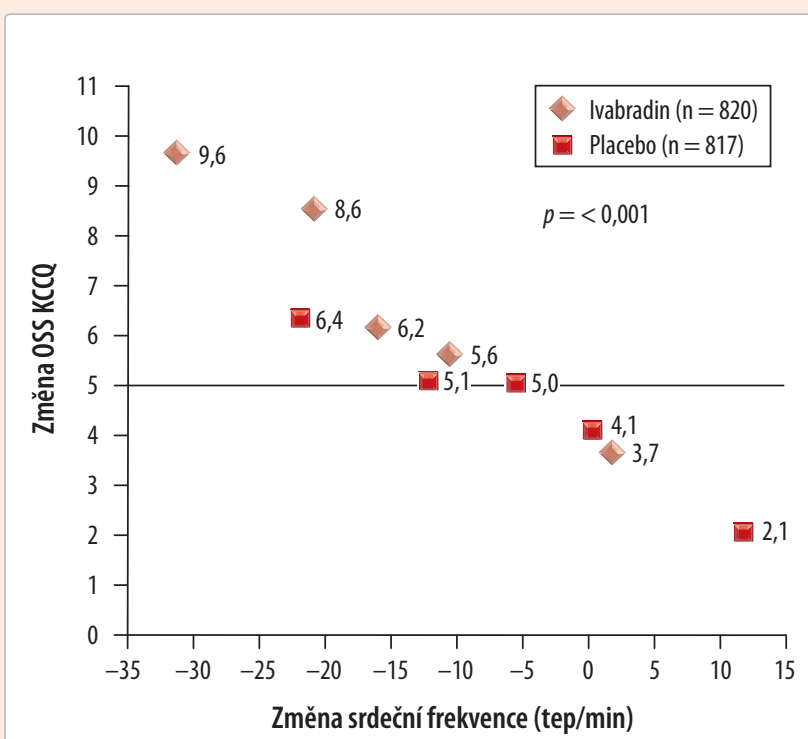

Ekman I. Eur Heart J. doi:10.1093/eurheartj/ehr343.

Obr. 2 Průměrné změny celkového souhrnného skóre OSS podle kvintilů změn srdeční frekvence po 12 měsících léčby

„Závěrem této podstudie SHIFT-HQoL tedy můžeme říci, že ivabradinem dosažené snížení závažnosti srdečního selhání, doložené nižším počtem hospitalizací a úmrtí a zlepšením klasi- fikace NYHA, se promítá i do kvality života, " uvedla prof. Inger Ekmanová z univerzity ve švédském Göteborgu, která tuto práci na kongresu prezentovala.

Druhá, echokardiografická subanalýza studie SHIFT potvrdila, že ivabradin potlačuje u nemocných se srdečním selháním remodelaci levé komory. Tato data prezentoval prof. Jean-Claude Tardif z Montreal Heart Institute při University of Montreal v Kanadě. Uvedl, že výsledky této analýzy vedou k závěru, že ivabradin modifikuje progresi onemocnění u pacientů se srdečním selháním, kteří již dostávají standardní terapii. To má podle něj důležité klinické implikace, protože remodelace myokardu je centrálním patofyziologickým mechanismem progredujícího srdečního selhání. „Naše echokardiografické klinické hodnocení prokázalo, že ivabradin signifikantně snižuje rozměry levé komory, inhibuje a zlepšuje remodeling a zlepšuje prečerpávací funkci srdce", prohlásil prof. Tardif.

Echokardiografické klinické hodnocení bylo provedeno u 411 pacientů. Echokardiogramy byly pořízeny při vstupu a po osmi měsících podávání ivabradinu nebo placeba. Primárním sledovaným parametrem podstudie SHIFT-ECHO byl vývoj indexu objemu levé komory na konci systoly (left ventricular end-systolic volume index, LVESVI), nebot u pacientů se srdečním selháním patří mezi nejvýznamnější prognostické ukazatele a odráží jak dilataci levé komory, tak

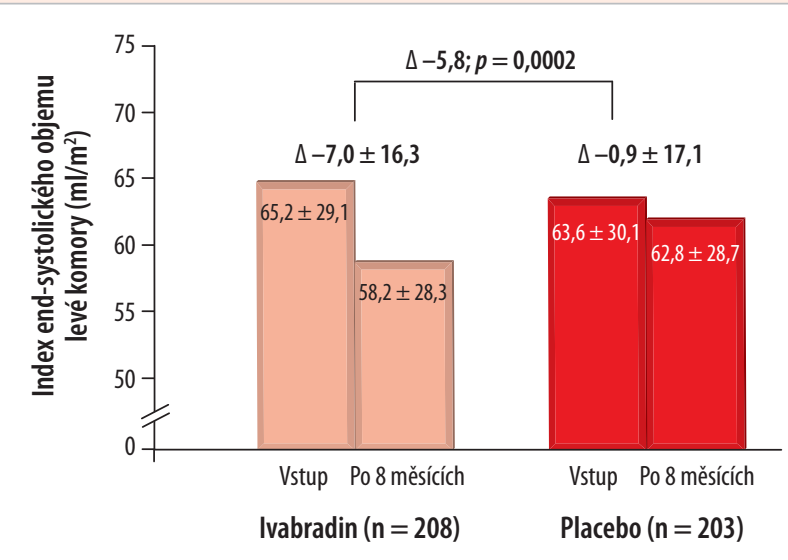

Tardif JC et al, EHJ doi:10.1093/eurheartj/ehr311

Obr. 3 Primární ukazatel podstudie SHIFT-ECHO: změna indexu objemu levé komory na konci systoly

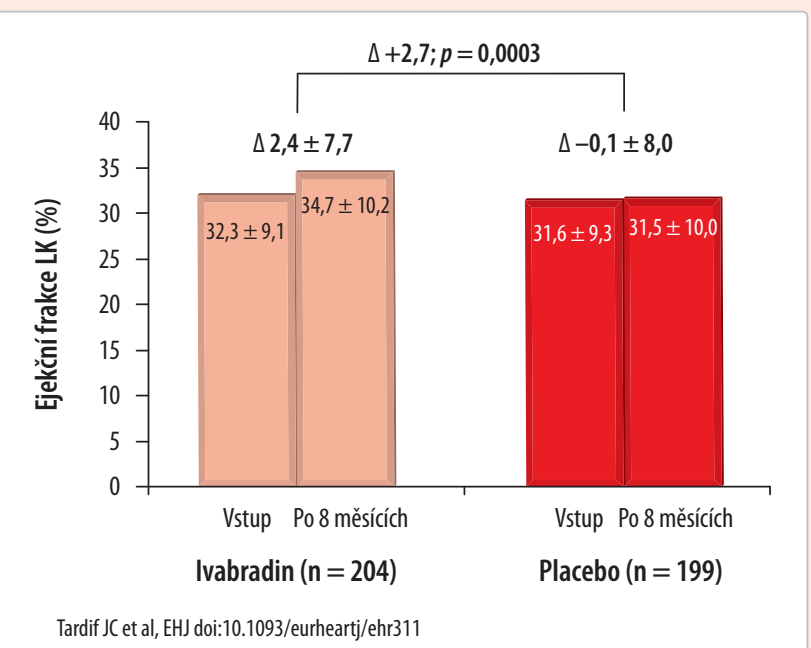

Obr. 4 Sekundární cílový ukazatel podstudie SHIFT-ECHO: změna ejekční frakce levé komory 
kontraktilitu myokardu. LVESVI se ve skupině s ivabradinem významně snížil ( $p=0,0002$ vs placebo), přičemž u $38 \%$ pacientů bylo toto snížení minimálně o $15 \%$ (viz obr. 3). Klinické hodnocení dále prokázalo, že ivabradin přidaný ke standardní léčbě (92\% pacientů užívalo beta-blokátory, $96 \%$ inhibitory ACE či sartany, $72 \%$ blokátor aldosteronu) signifikantně snižuje end-systolický a end-diastolický objem levé komory a zlepšuje její ejekční frakci (viz obr. 4 a tab. 1).

Placebová větev ukázala, že index objemu LK na konci systoly $\geq 59 \mathrm{ml} / \mathrm{m}^{2}$ (medián) při vstupu do studie byl spojen s $62 \%$ zvýšením relativního rizika primarního souhrnného sledovaného parametru studie SHIFT (KV mortalita nebo hospitalizace pro zhoršení srdečního selhání) ve srovnání s pacienty s LVESVI $<59 \mathrm{ml} / \mathrm{m}^{2}$ (viz obr. 5). Je to tedy další

Tab. 1 Další sledované parametry SHIFT-ECHO a jejich změny po osmi měsících léčby

\begin{tabular}{llll}
\hline & $\begin{array}{l}\text { Ivabradin } \\
(\mathbf{n}=304)\end{array}$ & $\begin{array}{l}\text { Placebo } \\
(\mathbf{n}=307)\end{array}$ & $p$ \\
\hline $\begin{array}{l}\text { Změna indexu objemu LK } \\
\text { na konci diastoly } \\
(\text { LVEDVI, ml/m²) }\end{array}$ & $-7,9$ & $-1,8$ & 0,002 \\
\hline $\begin{array}{l}\text { Změna objemu LK na konci } \\
\text { systoly (LVESV, ml) }\end{array}$ & $-13,0$ & $-1,3$ & $<0,001$ \\
\hline $\begin{array}{l}\text { Změna objemu LK na konci } \\
\text { diastoly (LVEDV, ml) }\end{array}$ & $-14,7$ & $-2,9$ & 0,001 \\
\hline $\begin{array}{l}\text { Změna klidové srdeční } \\
\text { frekvence (tep/min) }\end{array}$ & $-14,7$ & $-5,8$ & $<0,001$ \\
\hline
\end{tabular}

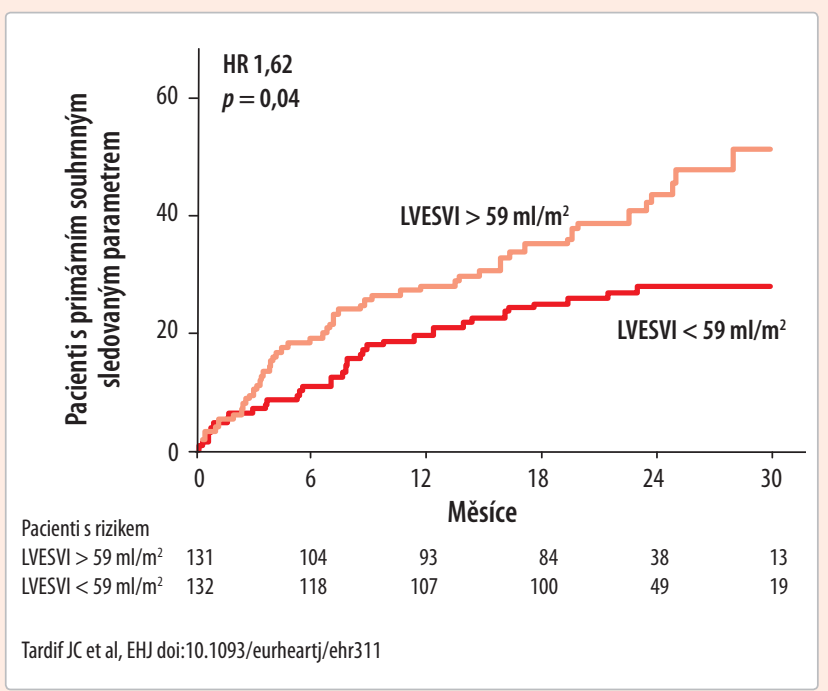

Obr. 5 Výskyt primárního složeného ukazatele studie SHIFT (KV mortalita/hospitalizace pro zhoršené srdeční selhání) podle průměrné hodnoty LVESVI (index end-systolického objemu levé komory) v placebové větvi

důkaz spojitosti mezi rizikem remodelace srdce a klinickými KV př́hodami.

„Studie přináši dalši poznatky hovořicí ve prospěch významu snížení srdeční frekvence ivabradinem při výsledném zmírnění remodelace srdce. Podstudie SHIFT-ECHO tak pomohla proniknout do podstaty mechanismu klinického prínosu ivabradinu u pacientů s chronickým srdečním selháním, "zakončil prof. Tardif. red 